\title{
Relationship between antibiotic resistance genes and metals in residential soil samples from Western Australia
}

\author{
Charles W Knapp ${ }^{1}$ • Anna C Callan ${ }^{2}$ • Beatrice Aitken ${ }^{1} \cdot$ Rylan Shearn ${ }^{3}$. \\ Annette Koenders $^{3}$ - Andrea Hinwood ${ }^{3}$
}

Received: 18 June 2016 / Accepted: 25 October 2016 / Published online: 7 November 2016

(C) The Author(s) 2016. This article is published with open access at Springerlink.com

\begin{abstract}
Increasing drug-resistant infections have drawn research interest towards examining environmental bacteria and the discovery that many factors, including elevated metal conditions, contribute to proliferation of antibiotic resistance (AR). This study examined 90 garden soils from Western Australia to evaluate predictions of antibiotic resistance genes from total metal conditions by comparing the concentrations of 12 metals and 13 genes related to tetracycline, beta-lactam and sulphonamide resistance. Relationships existed between metals and genes, but trends varied. All metals, except $\mathrm{Se}$ and $\mathrm{Co}$, were related to at least one AR gene in terms of absolute gene numbers, but only $\mathrm{Al}, \mathrm{Mn}$ and $\mathrm{Pb}$ were associated with a higher percentage of soil bacteria exhibiting resistance, which is a possible indicator of population selection. Correlations improved when multiple factors were considered simultaneously in a multiple linear regression model, suggesting the possibility of additive effects occurring. Soil-metal concentrations must be considered when determining risks of $\mathrm{AR}$ in the environment and the proliferation of resistance.
\end{abstract}

Responsible editor: Philippe Garrigues

Charles W Knapp

charles.knapp@strath.ac.uk

1 Department of Civil \& Environmental Engineering, University of Strathclyde, Glasgow, Scotland G1 1XJ, UK

2 School of Medical and Health Sciences, Edith Cowan University, Joondalup, WA 6027, Australia

3 Centre for Ecosystem Management, Edith Cowan University, Joondalup, WA 6027, Australia
Keywords Antimicrobial resistance $\cdot$ Antibiotic resistance Garden soil · Toxic heavy metal $\cdot$ qPCR

$\begin{array}{ll}\text { Abbreviations } \\ \text { 16S rRNA } & \text { 16S ribosomal ribonucleic acid } \\ \text { AR } & \text { Antibiotic resistance } \\ \text { ARG } & \text { Antibiotic resistance genes } \\ \text { bla } & \text { Beta-lactamase gene (-TEM, -SHV, -OXA and - } \\ & \text { CTX each represent a type of gene) } \\ \text { ICP-OES } & \text { Inductively coupled plasma optical } \\ & \text { emission spectrometry } \\ \text { PCR } & \text { Polymerase chain reaction } \\ \text { qPCR } & \text { Quantitative polymerase chain reaction } \\ \text { sul } & \text { Sulphonamide resistance gene } \\ \text { tet } & \text { Tetracycline resistance gene }\end{array}$

\section{Introduction}

Antibiotic resistance (AR) has become one of the most significant problems to threaten populations globally (WHO 2014), as the prevalence of multidrug-resistant bacterial infections continues to increase (Canton 2009; Tenover 2006). Generations of newly developed antibiotics lose their efficacy against many bacterial infections within a few years after their introduction (Davies and Davies 2010), and along with the difficulty to develop and supply new effective antibiotics (Shlaes 2010), antibiotic resistance threatens the effectiveness of chemical therapies. The rapid appearance of resistance traits suggests that a reservoir of resistance traits exists, and factors, other than those in the clinical setting, influence the dissemination of these genes. As such, attention has shifted towards the environment (Martinez 2008). 
Understanding the link between AR and environmental conditions remains crucial. The assumptions that AR solely originates from the misuse or overuse of antibiotics are no longer acceptable; even after efforts have been made for reduced and more controlled antibiotic applications, AR continues to increase. Resistance occurs not only by selective pressure caused by antibiotics but also due to contaminants that promote the dissemination of genetic elements by cross-resistance and co-resistance processes (Ashbolt et al. 2013; Baker-Austin et al. 2006; Berg et al. 2010; Perry and Wright 2013). Bacterial communities respond genetically to pollutants via evolved mechanisms for their self-protection (Alonso et al. 2001); in particular, potentially toxic metals contribute to the stress response (Ashbolt et al. 2013; Beaber et al. 2004; Berendock et al. 2015). As such, the environment acts both as a reservoir of resistance traits and a bioreactor containing chemical stressors and opportunities for genetic exchange. The potential for these traits to disseminate to clinically relevant pathogens becomes a consequence.

The relationship between metal tolerance (or resistance) and AR has been known; reviews can be found in the literature (e.g., Baker-Austin et al. 2006; Martinez 2009; Seiler and Berendonk 2012; Perry and Wright 2013). Certain metals, albeit toxic at high concentrations, contribute to the biochemical health of microorganisms; mechanisms exist for their regulation and handling. However, clinically relevant infections have been found resistant to multiple antimicrobials, including metals, by susceptibility assays (e.g., Bass et al. 1999; Dhakephalkar and Chopade 1994; Ghosh et al. 2000; Guo et al. 2014; Marques et al. 1979), suggesting that a link between genetic traits exists.

In the environment, relationships between metals and AR proliferation were first noticed in highly contaminated areas, including outflows of insufficiently treated wastewater and biosolids (Graham et al. 2011; Knapp et al. 2012; Su et al. 2015), land application of agricultural wastes (Ji et al. 2012; Li et al. 2015; Zhu et al. 2013), industrial contamination (Abella et al. 2015; Graham et al. 2011; Hu et al. 2016; Knapp et al. 2012; Stepanauskas et al. 2005; Wright et al. 2006) and direct application via metal exposure experiments (Berg et al. 2005, 2010; Knapp et al. 2011; Stepanauskas et al. 2006). AR presence in these cases has often been indicative of exposure to elevated metal pollution; however, limited information exists on less-impacted soils and requires further investigation to ascertain basal risks of AR, especially in residential areas.

Here, we compared total metal conditions and the presence of AR genes from soil samples collected from residences in a range of urban and regional areas in Western Australia. This investigation not only determines the risk of AR bacteria in residential garden soils but also elucidates the feasibility of predicting AR in soils, especially where potentially toxic metals exist at lower concentrations.

\section{Methods}

\section{Sample collection, preparation and characterisation}

Soil samples were collected from residential areas in Western Australia as part of the Australian Maternal Exposure to Persistent Toxic Substances (AMETS) study (Callan et al. 2013). The aim of the original study was to assess whether residential soil and dust were sources of pollutant exposure to pregnant women; sampling procedures were designed to optimise and to minimise sample handling and potential interference by vegetation. Participants resided in either the Perth metropolitan area (10\% samples) or regional towns in Western Australia (remaining 90\%) including Albany, Bunbury, Bridgetown, Nannup, Busselton, Dunsborough, Margaret River, Collie, Esperance, Geraldton, Kalgoorlie and Port Hedland, which are categorised as Inner Regional Australia, Outer Regional Australia or Remote by the Australian Standard Geographical Classification Remoteness Area system (Australian Institute of Health and Welfare 2004). Eighty samples were taken from areas with Mediterranean climate, and ten considered subtropical or tropical climate.

Soils were collected by volunteering homeowner sampling at least four bare areas of soil. They were instructed to take surface soil samples using a trowel or spoon in the boundary of the residential property and consolidated into a labelled plastic bad provided to them. No vegetation was required to be removed from the samples. There were no known contaminants on these properties; industries in the area included mining and agriculture.

Soil samples were collected between 2008 and 2011. They were mixed thoroughly, air dried ( 2 days at room temperature) and sieved (1.0-mm mesh). To minimise cross-contamination, the sieves were cleaned with a brush and fresh paper tissue and rinsed with acetone between samples. The samples were stored in sealed containers at room temperature.

Soil characterisation was undertaken on a subset of soil samples ( $n=59$, based on the mass of sample available). Soil particle size analysis was undertaken to determine the particle distribution using the Bouyoucos Hydrometer method based on established protocols (Sheldrick and Wang 1993; Day 1965). The organic matter content in soil samples was determined using weight loss on ignition (Schulte and Hopkins 1996; Schollenberger 1945). The $\mathrm{pH}$ and electrical conductivity of the soil samples in solution was measured using precalibrated $\mathrm{pH}$ and conductivity meters (Van Reeuwijk 2002; Rhoades 1982).

\section{Chemical analyses}

Approximately $1 \mathrm{~g}$ of soils was acid-digested for metal content with 1:1:1 $\mathrm{HNO}_{3}, 30 \% \mathrm{H}_{2} \mathrm{O}_{2}$ and concentrated $\mathrm{HCl}$ at 
$95{ }^{\circ} \mathrm{C}$ (USEPA 2002). Once cooled, digested samples were filtered (Whatman No. 41 filter paper) and brought to $100 \mathrm{~mL}$ final volume with deionised water.

Samples were analysed using a Varian Vista Pro Inductively Coupled Plasma Optical Emission Spectrometry (ICP-OES) (Varian Analytical Instruments, Australia) at the ECU laboratories. The metals analysed included aluminium, arsenic, cobalt, copper, lead, manganese, mercury, nickel, selenium, uranium, vanadium and zinc. The instrument was calibrated using five standard solutions achieving a standard calibration of $r^{2}>0.99$; standards and calibrations were checked several times during the analysis procedure using certified reference material RM 8704 (river sediment with $5 \mathrm{mg} / \mathrm{L}$ elemental spike; representing the concentration ranged needed for this study). Recoveries for elemental spikes ranged between 85 and $100 \%$ for all analyses, and replicate results remained within $10 \%$ coefficient of variation.

Ideally, knowing the extractable element content would have been useful for this analysis. However, the nature of prolonged sample storage in the archive and the natural soil 'ageing' process would have prevented accurate determinations. Given that, it was decided that the analysis would not have been worth the depletion of soils since only limited amounts remained in storage.

\section{Molecular microbial analysis}

Molecular biological analysis of each sample involved DNA extraction and purification using the PowerLyzer PowerSoil DNA Isolation Kit MB12855-50 (GeneWorks Pty Ltd., Hindmarsh, South Australia) with a Powerlyzer 24 benchtop, bead-based homogeniser. Several trials were undertaken to find a bead beating rate that provided an optimum yield with minimal DNA shearing. For this particular study, homogenisation at $3000 \mathrm{rpm}$ for $45 \mathrm{~s}$, followed by an incubation at $70{ }^{\circ} \mathrm{C}$ for $10 \mathrm{~min}$, then another bead beating step of $3000 \mathrm{rpm}$ for $25 \mathrm{~s}$ gave optimum yield with minimal DNA shearing for most samples. All DNA extraction protocol steps were performed at room temperature, aside from bead beating steps, which were performed in a cold room $\left(4^{\circ} \mathrm{C}\right)$. The degree of DNA shearing was examined using gel electrophoresis, and DNA extraction quality was verified using a NanoDrop spectrophotometer.

In each sample, quantitative PCR (Bio-Rad iCycler, Hampstead, UK) enumerated genes related to beta-lactam (bla $a_{\mathrm{TEM}}, b l a_{\mathrm{CTX}}, b l a_{\mathrm{SHV}}$ and $b l a_{\mathrm{OXA}}$ (Knapp et al. 2010)), sulphonamide (sul1, sul2 and sul3 (Pei et al. 2006)) and tetracycline resistance (tet $\mathrm{M}$ and tet $\mathrm{W}$ (Peak et al. 2007; Smith et al. 2004)) genes. Additionally, to screen as many tetracycline genes as possible, multiplex qPCR assays were used $(\mathrm{Ng}$ et al. 2001), where tet1 (tet $\mathrm{B}, \operatorname{tet} \mathrm{C}$ and $\operatorname{tet} \mathrm{D})$ and tet2 (tet $\mathrm{A}$, tet $\mathrm{E}$, tet $\mathrm{G}$ ) surveyed many efflux genes, tet 3 (tet $\mathrm{K}$, tet $\mathrm{L}$, tet $\mathrm{M}$, tet $\mathrm{O}$ and tet $\mathrm{S}$ ) represented a mix of efflux and ribosomal protection genes, and tet 4 included tet $\mathrm{A}(\mathrm{P})$ (efflux pump), tet $\mathrm{X}$ (enzyme) and tetQ (ribosomal protection protein). The selection of genes was not intended to be exhaustive, rather they provided key 'biomarkers' that have been routinely measured previously (e.g., Graham et al. 2011; Knapp et al. 2010; Knapp et al. 2011; Pei et al. 2006; Pruden et al. 2006). 16S ribosomal ribonucleic acid (16S rRNA) genes were also measured to determine relative abundances of ARG as a surrogate measure of 'total bacteria', using the $338 \mathrm{~F}-805 \mathrm{R}$ primer pair (5'-3'; with $515 \mathrm{~F}$ probe) that should minimise non-target binding to plant, animal and fungal DNA (Dorn-In et al. 2015).

Each $20 \mu \mathrm{L}$ reaction comprised of $10 \mu \mathrm{L}$ iQ Supermix (Bio-Rad), $7 \mu \mathrm{L}$ molecular-grade water (Qiagen; Hilden, Germany), $1 \mu \mathrm{L}$ primers (500 nM; Sigma-Aldrich; Haverhill, England), $2 \mu \mathrm{L}$ of DNA template and SYBR Green I for fluorescence detection. Temperature cycles involved $10 \mathrm{~min}$ at $95^{\circ} \mathrm{C}$ for initial denaturation and 40 cycles of denaturation $\left(1 \mathrm{~min}, 95^{\circ} \mathrm{C}\right)$, primer annealing $(30 \mathrm{~s}$, primerspecific temperature (see references listed above)) and elongation and fluorescence detection $\left(30 \mathrm{~s}, 72{ }^{\circ} \mathrm{C}\right)$. Genecontaining plasmids, each diluted in yeast tRNA solution to $10^{1}$ to $10^{7}$ copies per microlitre, were used as (neat) standard controls as prepared by Smith et al. (2004). Gene determinants tet $\mathrm{A}, t e t \mathrm{~B}, t e t \mathrm{O}$ and tet $\mathrm{Q}$ were used as controls for the tet multiplex assays. Before analysis, aliquots of randomly selected samples were serially diluted and analysed by PCR (targeting 16S rRNA gene); the resulting trend lines were compared with those of 'neat' standards; the lowest dilution, at which trend lines had comparable slopes with standards and generated minimal within-sample variability, was selected. As such, all samples were diluted 1:100 with molecular-grade water to minimise inhibitory effects on the PCR polymerase enzyme. Post-analytical quality control included a melt curve of PCR products to verify reaction quality $\left(50-95{ }^{\circ} \mathrm{C}\right.$, $\left.\Delta T=0.1^{\circ} \mathrm{C} / \mathrm{s}\right)$.

\section{Data analysis}

ARG data were analysed in two ways: raw abundances (per gram soil extracted) or relative abundances (normalised per 16S rRNA genes). Non-normalised data do not take into account the bacterial population size, meaning a sample containing a high number of ARG can either be attributed to many bacteria present in the samples or a high number of genes existing in the community. This is often used to compare gene flux in run-off and surfacewater scenarios (Knapp et al. 2012). Normalising gene counts to 16S rRNA genes (a surrogate measure of total bacteria) presents an approximate proportion of bacteria that carry the gene of interest.

All statistics involved SPSSTM version 20. Metal concentrations below the limit of detection (LOD) were assigned a value of half the LOD for analysis. Analyses included log transformation of gene values and soil metal concentrations to ensure 
distribution normality (Kolmogorov-Smirnov test). We predetermined significance level ( $\alpha$ value) at $10 \%$ to account for the variable nature of environmental samples. Bivariate Pearson's correlations were undertaken to determine the relationships between log-transformed soil metal concentrations and gene values. Multiple linear regression models were generated using log-transformed normalised gene content as the dependent variables and metal concentrations as the independent variables; the metals entered into the model were selected on the basis of bivariate correlations.

\section{Results and discussion}

\section{Environmental conditions}

Soils were collected from 90 sites in Western Australia; the composition of the soils was predominantly sand ( $\geq 70 \%)$, with $\mathrm{pH}$ ranging from slightly acidic to neutral and a range of organic matter content (Table 1). Further, soils were analysed for aluminium, arsenic, cobalt, copper, mercury, manganese, nickel, lead, selenium, uranium, vanadium and zinc content (Callan et al. 2013; Hinwood et al. 2013) (Table 1). While most values ranged within values typical of 'background' in Europe (McLaughlin et al. 2010) and Australian soils (NEPC 1999), there were a few minor exceptions. High vanadium (>50 mg/kg), selenium (>200 mg/kg) and mercury levels $(>1 \mathrm{mg} / \mathrm{kg}$ ) were found at a few sites, but they were within Soil Quality Standards for Europe and the National
Environment Protection Measures (NEPM) guidelines for 'no action' in residential areas in Australia (NEPC 1999). As would be anticipated, the proportion of sand in the soil samples was negatively correlated with the proportion of silt and clay ( $r=-0.857, p<0.001$ and $r=-0.756, p<0.001$, respectively) and also with the electrical conductively of the soils $(r=-0.396$, $p=0.002)$ and the presence of organic matter $(r=-0.439$, $p=0.001)$.

For the metals manganese, nickel, selenium and vanadium, the concentrations of these metals in soil samples were found to be negatively correlated with the proportion of sand and positively correlated with the percentage of silt and clay: Mn (sand, $r=-0.745, p<0.001$; silt, $r=0.704, p<0.001$; clay, $r=0.481, p<0.001$ ), Ni (sand, $r=-0.480, p<0.001$; silt, $r=0.466, p<0.001$; clay, $r=0.293, p=0.023$ ), Se (sand, $r=-0.339, p=0.009$; silt, $r=0.362, p=0.005$; clay, $r=0.165, p=0.211$ ) and $\mathrm{V}$ (sand, $r=-0.755, p<0.001$; silt, $r=0.723, p<0.001$; clay, $r=0.474, p<0.001)$. The concentration of aluminium in the soil samples was negatively correlated with soil $\mathrm{pH}(r=-0.505, p<0.001)$, with higher concentrations identified in more acidic soils, which may reflect increased solubility.

DNA was extracted from a subset of the soils and analysed for 16S rRNA and selected AR genes (Table 2) and resulted in an array of total gene values ranging from $10^{-6}$ to $10^{-2}$ genes/ $16 \mathrm{~S}$ rRNA, representing approximately 0.0001 to $1 \%$ of the total bacteria. AR gene concentrations ranged from those typical in 'pristine' environments to those found in 'impacted' sites (e.g., Graham et al. 2011; Pruden et al. 2006).
Table 1 Soil character and metal concentrations $(\mathrm{mg} / \mathrm{kg})$ in samples collected throughout Western Australia $(n=90)$

\begin{tabular}{|c|c|c|c|}
\hline & Mean $(95 \% \mathrm{CI})$ & Min-max & $<\% \mathrm{LOD}^{\mathrm{a}}$ \\
\hline$\%$ Sand & $88.2(1.9)$ & $70.0-97.5$ & \\
\hline$\%$ Silt & $6.0(1.3)$ & $0.5-23.0$ & \\
\hline$\%$ Clay & $5.9(1.0)$ & $0.0-19.5$ & \\
\hline $\mathrm{pH}$ & $7.0(0.1)$ & $5.7-8.1$ & \\
\hline Electrical conductivity $(\mu \mathrm{S} / \mathrm{cm})$ & $419(80)$ & $22-1890$ & \\
\hline$\%$ Organic matter & $6.2(0.8)$ & $1.5-13.9$ & \\
\hline Aluminium & $1800(450)$ & $<2.50-13,000$ & 2.2 \\
\hline Arsenic & $4.91(0.96)$ & $<3.50-22.9$ & 57.8 \\
\hline Cobalt & $0.75(0.11)$ & $<1.00-2.78$ & 76.7 \\
\hline Copper & $7.46(1.83)$ & $<0.04-48.3$ & 13.3 \\
\hline Mercury & $1.31(0.55)$ & $<1.0-17.0$ & 81.1 \\
\hline Manganese & $49.9(13.4)$ & $<0.20-443$ & 2.2 \\
\hline Nickel & $2.26(0.60)$ & $<2.00-19.1$ & 70.0 \\
\hline Lead & $9.27(2.96)$ & $<3.00-96.4$ & 50.0 \\
\hline Selenium & $14.6(8.8)$ & $<3.00-293$ & 71.1 \\
\hline Uranium & $21.5(13.2)$ & $<1.00-592$ & 23.3 \\
\hline Vanadium & $13.3(4.4)$ & $<0.30-97.1$ & 5.6 \\
\hline Zinc & $33.2(8.5)$ & $<0.60-197$ & 7.8 \\
\hline
\end{tabular}

${ }^{a}<\%$ LOD indicates proportion of samples below respective analytical limit of detection for that metal 
Table 2 Gene content (log-transformed) in samples collected throughout Western Australia

\begin{tabular}{lcccc}
\hline & $\begin{array}{l}\text { Absolute abundance } \\
l o g(\text { genes/g soil) }\end{array}$ & \multicolumn{2}{l}{$\begin{array}{l}\text { Relative abundance } \\
l o g(\text { genes/16S rRNA })\end{array}$} \\
& Mean (95\% CI) & Min/max & Mean (95\% CI) & Min/max \\
16S rRNA & $9.32(0.17)$ & $7.11 / 10.06$ & & \\
bla $_{\text {TEM }}$ & $6.41(0.22)$ & $2.60 / 8.42$ & $-3.01(0.22)$ & $-7.31 /-0.35$ \\
bla $_{\text {CTX }}$ & $3.46(0.11)$ & $1.65 / 4.00$ & $-4.04(0.16)$ & $-8.07 /-3.67$ \\
bla $_{\text {OXA }}$ & $5.00(0.09)$ & $3.50 / 6.38$ & $-4.33(0.17)$ & $-6.38 /-1.79$ \\
bla $_{\text {SHV }}$ & $5.11(0.23)$ & $2.92 / 6.47$ & $-4.16(0.23)$ & $-8.03 /-2.12$ \\
Tet1 & $4.67(0.29)$ & $2.36 / 6.32$ & $-4.40(0.30)$ & $-7.28 /-1.29$ \\
Tet2 & $5.59(0.37)$ & $2.65 / 7.98$ & $-3.47(0.38)$ & $-7.03 /-1.80$ \\
Tet3 & $5.51(0.24)$ & $3.05 / 7.37$ & $-3.65(0.25)$ & $-6.95 /-1.85$ \\
Tet4 & $6.63(0.14)$ & $4.26 / 7.72$ & $-2.69(0.18)$ & $-5.47 /-1.51$ \\
tet $(\mathrm{M})$ & $5.89(0.14)$ & $4.20 / 7.27$ & $-3.47(0.20)$ & $-5.70 /-1.01$ \\
tet $(\mathrm{W})$ & $4.48(0.20)$ & $1.89 / 7.19$ & $-5.15(0.25)$ & $-7.75 /-2.44$ \\
sul 1 & $5.02(0.30)$ & $1.25 / 6.72$ & $-4.48(0.31)$ & $-8.37 /-1.74$ \\
sul2 & $4.85(0.19)$ & $1.29 / 6.59$ & $-4.58(0.21)$ & $-8.48 /-2.04$ \\
sul3 & $4.79(0.19)$ & $2.66 / 7.24$ & $-4.51(0.24)$ & $-7.04 /-1.71$ \\
\hline
\end{tabular}

\section{Bivariate correlations — absolute abundances}

We assessed the relationships between metals and the abundances of AR genes in the soils to determine whether metals were likely to influence AR gene presence. Examining absolute gene abundances, representing the amount of genes per gram of soil, correlational analyses (Table 3) found a number of genes related to metal concentrations. In particular, manganese and vanadium levels exhibited the greatest number of significant correlations to AR genes: $b l a_{\mathrm{CTX}}, b l a_{\mathrm{OXA}}$, bla $a_{\mathrm{TEM}}$, tet4 series, tet $\mathrm{M}$, tet $\mathrm{W}$, sul1 and sul2; however, they simultaneously correlated with $16 \mathrm{~S}$ rRNA genes (Mn, $r=0.261 ; p=0.013 ; \mathrm{V}, r=0.211, p=0.046)$, suggesting co-linearity of data. Correlation values may reflect increasing numbers of bacteria overall, with similar proportions of the communities having the genes. Ignoring the metals that had correlations with $16 \mathrm{~S}$ rRNA genes (which also included nickel $r=0.199, p=0.061$ ), significant correlations were found with copper (with $\left.b l a_{\mathrm{OXA}}, b l a_{\mathrm{TEM}}, t e t \mathrm{M}\right)$ and aluminium (bla $a_{\mathrm{OXA}}$, bla ${ }_{\mathrm{TEM}}$, tet $\mathrm{M}$, tet $\mathrm{W}$, sul2 and sul3).

Genes $b l a_{\mathrm{OXA}}$ and $b l a_{\mathrm{TEM}}$ had the greatest number of positive relationships with metal concentrations: aluminium, copper, manganese, nickel, vanadium and zinc; bla ${ }_{\mathrm{TEM}}$ also correlated with uranium concentrations, whereas $b l a_{\mathrm{OXA}}$ correlated with lead. Additional correlations included $b l a_{\mathrm{SHV}}$ and arsenic, tet 2 series and mercury and $b l a_{\mathrm{CTX}}$ and uranium. There were some negative correlations among tet 2 notably with lead $(r=-0.249, p=0.020)$ and vanadium $(r=-0.177$, $p=0.100$ ), which suggested that specific populations could have been negatively impacted by these metals.
Copper and zinc have been reported in literature to be strong contributors to absolute abundance of resistance traits in soils, having direct correlations with beta-lactam (Hölzel et al. 2012; Hu et al. 2016; Knapp et al. 2011), sulphonamide (Hu et al. 2016; Ji et al. 2012), erythromycin (Knapp et al. 2011) and tetracycline resistance (Knapp et al. 2011; Peltier et al. 2010). Bacterial cells biochemically require these elements, although elevated levels are toxic; as such, they have mechanisms to maintain homeostasis in cells, and some traits that promote tolerance to higher concentrations can be found on mobile genetic elements along with antibiotic resistance genes (e.g., Hasman and Aarestrup 2005). While this study supports previous studies with positive correlations found between copper and/or zinc and the number of antibiotic resistance genes, most studies examined elevated levels of metal pollution. Here, environmental conditions with lower levels of metals were examined.

\section{Bivariate correlations - relative (per total bacteria) abundances}

When normalised to $16 \mathrm{~S}$ rRNA, the correlation patterns changed, and many relationships became less apparent, which may not be surprising given the prevalence of 'lower' metal concentrations. However, $b l a_{\mathrm{TEM}} / 16 \mathrm{~S}$ continued to be impacted by metal concentrations with positive correlations with aluminium, manganese, lead and uranium. Correlations remained significant among metals and other beta-lactam resistance genes: arsenic and $b l a_{\mathrm{SHV}} / 16 \mathrm{~S}$, lead and $b l a_{\mathrm{OXA}} /$ $16 \mathrm{~S}$ and uranium and bla $_{\mathrm{CTX}} / 16 \mathrm{~S}$.

Limited correlations between relative gene abundances and soil character were found. Most correlations were weak and insignificant, except negative correlations were found with $b_{l a x} / 16 \mathrm{~S}(r=-0.338, p=0.010)$, tet $\mathrm{M} / 16 \mathrm{~S}$ $(r=-0.406, p=0.005)$, sul2/16S $(r=0.296, p=0.028)$ and sul3/16S $(r=-0.289, p=0.036)$.

The decrease in number of correlated pairs may be attributed to the relatively low metal concentrations in this study (as compared to many found in literature); the remaining pairwise relationships were likely to have been toxic. With the exception of manganese, these metals had no (or very limited) nutritional benefit to bacteria. Bacterial responses to metals, like antibiotics, are concentration dependent (Bernier and Surette 2013). At lower levels, some elements provide micronutrition for biochemical reactions as essential enzyme co-factors. At elevated concentrations, they become toxic, and exposure can lead to series of possible cellular stress responses (gene expression), community adaptation (including mutation and resistance development) or cell death.

There would be fewer strategies for cells to detoxify nonessential elements, which can adversely impact microbial populations. In this case, survivors would have developed 
Table 3 Significant bivariate correlations between metal content and relative AR gene abundances (normalised to $16 \mathrm{~S}$ rRNA gene abundance)

\begin{tabular}{|c|c|c|c|c|}
\hline \multirow[b]{2}{*}{$b l a_{\mathrm{TEM}}$} & \multicolumn{2}{|c|}{ Absolute (unnormalised) gene relationships } & \multicolumn{2}{|c|}{ Relative (normalised to $16 \mathrm{~S}$ ) gene relationships } \\
\hline & $\mathrm{Al}$ & $(r=0.29 ; p=0.01)$ & $\mathrm{Al}$ & $(r=0.20 ; p=0.08)$ \\
\hline & $\mathrm{Cu}$ & $(r=0.26 ; p=0.02)$ & $\mathrm{Mn}$ & $(r=0.20 ; p=0.07)$ \\
\hline & $\mathrm{Mn}$ & $(r=0.45 ; p<0.01)$ & $\mathrm{Pb}$ & $(r=0.22 ; p=0.05)$ \\
\hline & $\mathrm{Ni}$ & $(r=0.24 ; p=0.03)$ & $\mathrm{U}$ & $(r=0.22 ; p=0.05)$ \\
\hline & $\mathrm{U}$ & $(r=0.19 ; p=0.08)$ & & \\
\hline & $\mathrm{V}$ & $(r=0.32 ; p<0.01)$ & & \\
\hline & $\mathrm{Zn}$ & $(r=0.30 ; p=0.01)$ & & \\
\hline \multirow[t]{3}{*}{ bla $_{\mathrm{CTX}}$} & $\mathrm{Mn}$ & $(r=0.29 ; p=0.01)$ & $\mathrm{U}$ & $(r=0.30 ; p=0.01)$ \\
\hline & V & $(r=0.23 ; p=0.05)$ & & \\
\hline & $\mathrm{U}$ & $(r=0.23 ; p=0.05)$ & & \\
\hline \multirow[t]{7}{*}{$b l a_{\mathrm{OXA}}$} & $\mathrm{Al}$ & $(r=0.32 ; p<0.01)$ & $\mathrm{Pb}$ & $(r=0.26 ; p=0.01)$ \\
\hline & $\mathrm{Cu}$ & $(r=0.31 ; p<0.01)$ & & \\
\hline & $\mathrm{Mn}$ & $(r=0.38 ; p<0.01)$ & & \\
\hline & $\mathrm{Ni}$ & $(r=0.18 ; p=0.09)$ & & \\
\hline & $\mathrm{Pb}$ & $(r=0.25 ; p=0.02)$ & & \\
\hline & V & $(r=0.27 ; p=0.01)$ & & \\
\hline & $\mathrm{Zn}$ & $(r=0.35 ; p<0.01)$ & & \\
\hline \multirow[t]{3}{*}{$b l a_{\mathrm{SHV}}$} & As & $(r=0.20 ; p=0.07)$ & As & $(r=0.28 ; p=0.01)$ \\
\hline & & & $\mathrm{Ni}$ & $(r=-0.28 ; p=0.01)$ \\
\hline & & & V & $(r=-0.20 ; p=0.06)$ \\
\hline \multicolumn{5}{|l|}{ Tet1 } \\
\hline \multirow[t]{6}{*}{ Tet2 } & $\mathrm{Hg}$ & $(r=0.25 ; p=0.02)$ & $\mathrm{Hg}$ & $(r=0.23 ; p=0.03)$ \\
\hline & $\mathrm{Pb}$ & $(r=-0.25 ; p=0.02)$ & $\mathrm{Mn}$ & $(r=-0.21 ; p=0.06)$ \\
\hline & V & $(r=-0.18 ; p=0.10)$ & $\mathrm{Ni}$ & $(r=-0.25 ; p=0.02)$ \\
\hline & & & $\mathrm{Pb}$ & $(r=-0.18 ; p=0.10)$ \\
\hline & & & $\mathrm{Se}$ & $(r=-0.19 ; p=0.09)$ \\
\hline & & & V & $(r=-0.27 ; p=0.01)$ \\
\hline Tet3 & & & $\mathrm{Se}$ & $(r=-0.19 ; p=0.07)$ \\
\hline \multirow[t]{2}{*}{ Tet4 } & $\mathrm{Mn}$ & $(r=0.23 ; p=0.03)$ & & \\
\hline & V & $(r=0.21 ; p=0.05)$ & & \\
\hline \multirow[t]{3}{*}{$\operatorname{tet}(\mathrm{M})$} & $\mathrm{Al}$ & $(r=0.20 ; p=0.09)$ & Co & $(r=0.19 ; p=0.09)$ \\
\hline & $\mathrm{Mn}$ & $(r=0.26 ; p=0.03)$ & & \\
\hline & $\mathrm{Cu} \mathrm{Zn}$ & $(r=0.24 ; p=0.04)$ & & \\
\hline \multirow[t]{4}{*}{$\operatorname{tet}(\mathrm{W})$} & $\mathrm{Al}$ & $\begin{array}{l}(r=0.26 ; p=0.03) \\
(r=0.27 ; p=0.02)\end{array}$ & & \\
\hline & $\mathrm{Mn}$ & $(r=0.40 ; p<0.01)$ & & \\
\hline & $\mathrm{V}$ & $(r=0.32 ; p=0.01)$ & & \\
\hline & $\mathrm{Zn}$ & $(r=0.26 ; p=0.03)$ & & \\
\hline \multirow[t]{2}{*}{ sul1 } & $\mathrm{Mn}$ & $(r=0.27 ; p=0.01)$ & & \\
\hline & $\mathrm{V}$ & $(r=0.18 ; p=0.09)$ & & \\
\hline \multirow[t]{3}{*}{ sul2 } & $\mathrm{Al}$ & $(r=0.19 ; p=0.09)$ & & \\
\hline & $\mathrm{Mn}$ & $(r=0.30 ; p=0.01)$ & & \\
\hline & V & $(r=0.33 ; p<0.01)$ & & \\
\hline sul3 & $\mathrm{Al}$ & $(r=0.19 ; p=0.09)$ & & \\
\hline
\end{tabular}

Both variables were log-transformed to distribute the data better prior to correlation analysis or acquired specific resistance traits. The bias in correlation patterns appeared to be related to whether the metals contribute a nutritional need at lower concentrations. As mentioned previously, manganese, copper and zinc contribute to absolute gene abundances, suggesting that the cells are better adapted to survive at higher concentrations by biochemical mechanisms that exist (either innate or acquired) to assist the sequestration and handling of metals. In contrast, there are 
fewer adaptations for the non-nutritional metals, and populations would consequently become stressed.

Chromium, lead, arsenic, mercury, nickel and iron have been previously found related to ARG (Ji et al. 2012; Knapp et al. 2011; Timoney et al. 1978). However, there has been inconsistency in results with both positive and negative correlations being reported. For example, Hölzel et al. (2012) found that mercury and lead, which are not associated with known biochemical reactions, inhibited bacterial population growth rather than resistance development. In this study, aluminium, vanadium and lead (and to a limited extent, uranium) impacted microbial communities.

\section{Multiple linear regression models}

While significant relationships existed between AR and potential toxic metals in bivariate analysis, correlation coefficients ( $r$ values) were low. The complexity of soil environments makes it difficult to parameterise all possible factors that might contribute to AR (Knapp et al. 2011). Upon examination of scatterplots (see Fig. 1), higher range of gene values (normalised to $16 \mathrm{~S}$ rRNA) existed at lower concentrations; for example, elevated proportions of bacteria having ARG may be present despite potentially low exposure to a particular metal, suggesting that another element or factor
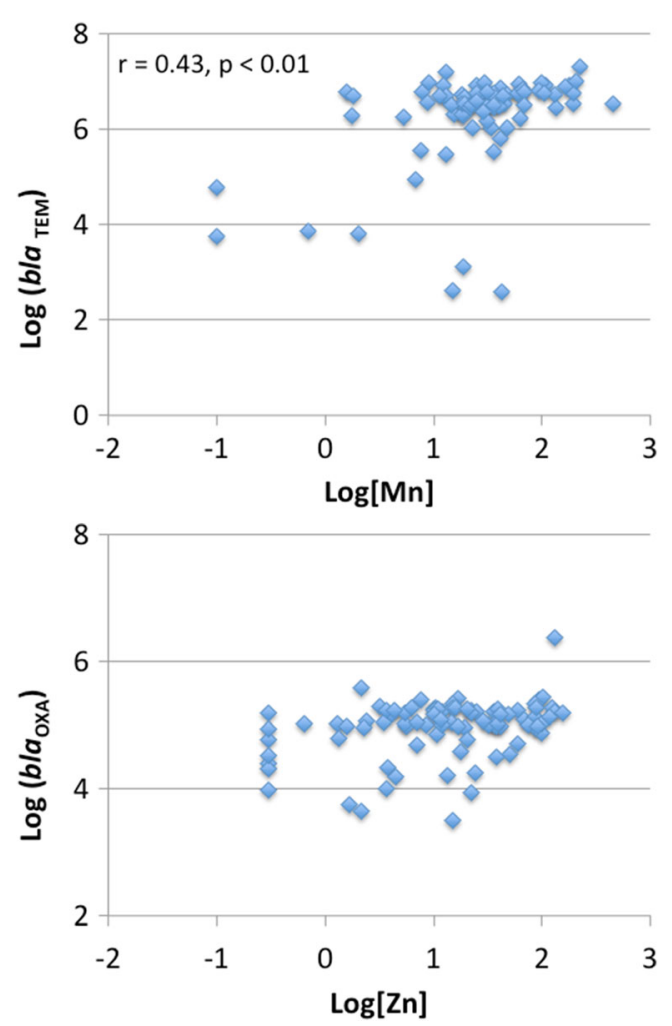

Fig. 1 Exemplar scatterplots demonstrating typical heteroscedastic patterns in bivariate analysis may be impacting the populations. With bivariate correlations, exposure-related effects may not become apparent until the contribution to AR by an individual metal exceeds the contribution by other factors. As such, the heteroscedastic nature of the data suggests that multiple factors influence AR gene abundances. For this reason, we also examined multiple linear regression (MLR) patterns.

The following seven metals were entered into a MLR model: aluminium, copper, manganese, nickel, lead and zinc based on their bivariate relationships. We used the model to predict relative gene abundances, as we focused on gene selection. More strongly significant correlations were found (Table 4; Fig. 2): $b l a_{\text {СтX }}(R=0.54, p<0.01), b l a_{\text {OXA }}$ $(R=0.45, p=0.01), b l a_{\mathrm{SHV}}(R=0.44, p=0.02)$, tet2 gene series $(R=0.54, p<0.01)$, sul2 $(R=0.50, p<0.01)$ and sul3 $(R=0.38, p=0.10)$.

When combining factors in a multilinear regression model, the relationship between soil heavy metal conditions and antibiotic resistance improved, suggesting that multiple stressors may additively drive the selection of resistance. Here, even at the low metal concentrations in the residential soils in this study, approximately $25 \%$ of the variation in the incidence of genetic markers of antibiotic resistance was explained by the models (Table 4).

\section{Link between metals and antibiotic resistance}

The linkage between antibiotic resistance and metal exposure has been known for many decades, when it was first discovered that penicillinase was linked with mercury exposure (Fraser 1971; Richmond et al. 1964). Two mechanisms are involved in the possible linkages. Cross-resistance involves a single gene that confers resistance to both the antibiotic and metal, e.g., an efflux pump. Co-resistance is when separate traits are closely linked, e.g., on a transferable genetic element or operon, and are transferred together (e.g., Richmond et al. 1964). In both cases, metal exposure is sufficient to select and maintain AR genotype (Baker-Austin et al. 2006).

Some metals can directly trigger the resistance phenotype. Tetracycline resistance genes tet $\mathrm{B}$, tet $\mathrm{C}$ and tet $\mathrm{D}$ (tet 1 series) and tet $\mathrm{A}$, tet $\mathrm{E}$ and $\operatorname{tet} \mathrm{G}$ (tet2 series) represent tetracyclinemetal porters (efflux pumps) and are known to affect divalent cations in cells [e.g., $\mathrm{Zn}^{+2}$ and $\mathrm{Cu}^{+2}$; (Yamaguchi et al. 1990)], and the metal-tetracycline complex is capable of mediating the activity of tetR, a repressor protein associated with tet determinants in gram-negative bacteria (Palm et al. 2008). Our results confirm the linkage between tetracyclineresistant genes and the divalent cations $\mathrm{Zn}^{+2}$ and $\mathrm{Cu}^{+2}$, as well as $\mathrm{Mn}^{+2}$.

On the other hand, tet $\mathrm{M}$ and $\operatorname{tet} \mathrm{W}$, along with $\operatorname{tet} \mathrm{O}$, tet $\mathrm{Q}$ and tet $\mathrm{S}$ (part of the tet 3 and tet 4 series), are ribosomal protection proteins. While the exact biochemical mechanism(s) 
Table 4 Multiple linear regression models for gene predictions

\begin{tabular}{|c|c|c|c|c|c|c|c|c|c|c|c|}
\hline \multirow{2}{*}{$\begin{array}{l}\text { Dependent } \\
\text { variable }\end{array}$} & \multirow{2}{*}{$\begin{array}{l}\text { Correlation } \\
(R)\end{array}$} & \multirow{2}{*}{$\begin{array}{l}F \\
\text { score }\end{array}$} & \multirow{2}{*}{$\begin{array}{l}\text { Significance } \\
\text { ( } p \text { value) }\end{array}$} & \multirow{2}{*}{$\begin{array}{l}\text { Model: } \\
\text { Constant }\end{array}$} & \multicolumn{7}{|l|}{ Coefficients: } \\
\hline & & & & & $\mathrm{Al}$ & $\mathrm{Cu}$ & $\mathrm{Mn}$ & $\mathrm{Ni}$ & $\mathrm{Pb}$ & $\mathrm{Se}$ & $\mathrm{Zn}$ \\
\hline$b l a_{\mathrm{TEM}} / 16 \mathrm{~S}$ & 0.362 & 1.57 & 0.157 & -3.202 & 0.00001 & 0.0133 & 0.00388 & -0.0317 & $0.0242 *$ & -0.00619 & -0.00531 \\
\hline$b l a_{\mathrm{CTX}} / 16 \mathrm{~S}$ & 0.535 & 3.715 & 0.002 & -6.230 & $0.00015^{*}$ & -0.0123 & 0.00120 & -0.0409 & 0.0169 & $0.00545^{*}$ & -0.0047 \\
\hline$b l a_{\mathrm{OXA}} / 16 \mathrm{~S}$ & 0.450 & 2.898 & 0.009 & -4.437 & $0.00011 *$ & -0.00059 & -0.00108 & -0.0506 & $0.0182 *$ & 0.00191 & -0.00387 \\
\hline$b l a_{\mathrm{SHV}} / 16 \mathrm{~S}$ & 0.435 & 2.696 & 0.015 & -4.068 & 0.00011 & 0.0154 & -0.00425 & $-0.111 *$ & -0.00335 & $0.00704 *$ & -0.00014 \\
\hline Tet1 & 0.337 & 1.132 & 0.254 & -4.222 & 0.00010 & -0.0464 & -0.00322 & -0.0975 & 0.00175 & 0.00383 & 0.00993 \\
\hline Tet2 & 0.540 & 4.645 & $<0.001$ & -3.093 & 0.00016 & 0.0802 & $-0.0106 *$ & -0.0385 & -0.0209 & 0.00309 & $-0.0146 *$ \\
\hline Tet3 & 0.234 & 0.654 & 0.710 & -3.481 & -0.00001 & -0.0259 & -0.00173 & -0.0199 & 0.0138 & -0.00019 & 0.00122 \\
\hline Tet4 & 0.336 & 1.456 & 0.195 & -2.622 & 0.00001 & -0.0110 & -0.00195 & -0.0534 & 0.0128 & 0.00214 & -0.00086 \\
\hline tetM & 0.421 & 1.965 & 0.074 & -3.551 & $0.00014 *$ & 0.0113 & -0.00138 & -0.0976 & 0.00678 & 0.00241 & -0.00294 \\
\hline tet $W$ & 0.317 & 1.056 & 0.402 & -5.231 & 0.00013 & 0.0202 & 0.00348 & -0.109 & 0.00753 & -0.00351 & -0.00705 \\
\hline sul1 & 0.344 & 1.453 & 0.197 & -4.602 & $0.00022 *$ & -0.0280 & 0.00168 & -0.0331 & -0.00547 & -0.00076 & -0.00064 \\
\hline sul2 & 0.498 & 3.670 & 0.002 & -4.564 & $0.00013 *$ & $-0.0402 *$ & 0.00034 & -0.0251 & 0.0206* & 0.00066 & -0.00349 \\
\hline sul3 & 0.384 & 1.780 & 0.105 & -5.511 & 0.00010 & -0.0167 & -0.00305 & -0.0142 & 0.0199 & 0.00295 & -0.00318 \\
\hline
\end{tabular}

Significant predictors, their coefficients and $p$ value are included; coefficients in bold represent significant $(p<0.05)$ contributions. The $R$ represents the coefficient of determination for the entire model; parameters entered into the model included aluminium, copper, manganese, nickel, lead, selenium and zinc

for co-resistance are not known, they have been reported to be associated with metal pollution (Berg et al. 2005; Knapp et al. 2011). Many of these genes, however, are associated with conjugative transposons (e.g., Tn917 and the Tn916-
1525 family), which are often associated with multiple resistance (Roberts 2012). Beta-lactam resistance has been associated with mercury (e.g., Fraser 1971; Richmond et al. 1964) and copper (e.g., Knapp et al. 2011) exposure,
Fig. 2 Observed versus predicted values (per 16S rRNA values) based on multilinear regression analysis. Significant $(p<0.01)$ patterns presented

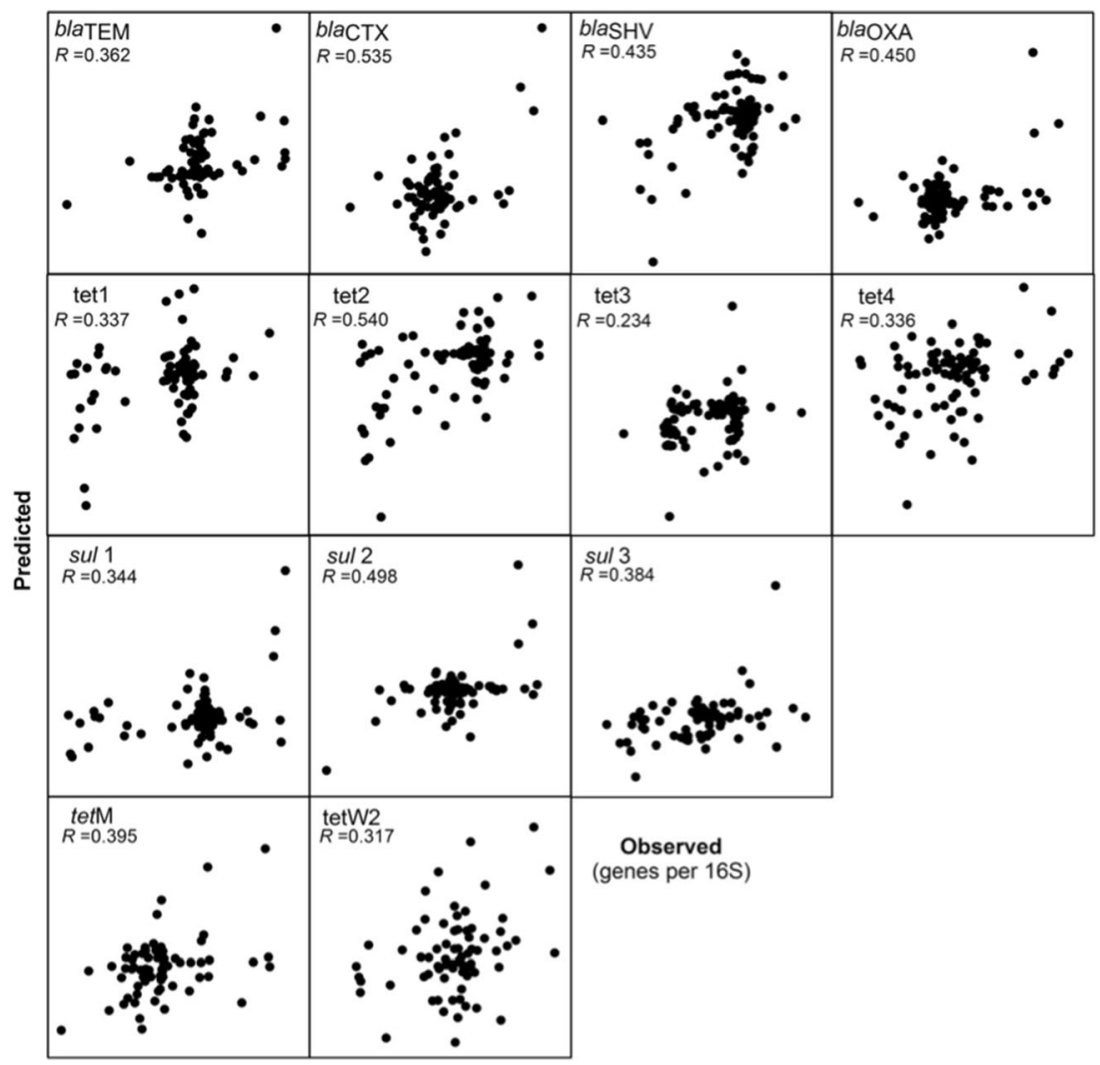


and lead exposure contributed to AR in enteric bacteria in poultry (Nisanian et al. 2014). The results from our study indicate linkage with other metals, namely aluminium, manganese, uranium and lead. Correlations have been reported between sul genes and copper, zinc and mercury in wastewater (Ji et al. 2012), whereas we again did not find a relationship with mercury, although there was a correlation with manganese in addition to aluminium and vanadium. Soil mercury concentrations in this study were very low (with over $80 \%$ of samples $<\mathrm{LOD}$ ), and this is likely to have precluded detection of a relationship between this metal and AR genes.

There is no information on previous management of the garden soils, which is unfortunate. Some garden amendments could contain both metals and ARG. However, the results of this study suggest that there are relationships, although weak, between metals and ARG concentration. Improvements to the study, and certainly worth considering for future experiments, include sequential metal extractions and some indication of their bioavailability and also the determination of threshold toxicity, especially among metals that have nutritional importance, and determination of whether resistance traits are innate to the cell or acquired, which may carry a greater risk of transfer. Here, given the nature of the archived soils, it would have been impossible to conduct these analyses. However, the results do suggest an avenue further research, especially since landscape contributors to ARG and basal levels in the environment remain poorly understood.

\section{Conclusions}

It is known that the presence of metals, at sufficient concentrations, results in metal tolerance (or resistance), which has (in turn) been proven to link to antibiotic resistance. This suggests that AR traits will be selected by metals, even in the absence of antibiotics. This study demonstrated that even at low concentrations of metals (including aluminium, copper, manganese and lead) in residential soils, antibiotic resistance was selected, as evidenced by increased relative gene abundances.

Many aspects of antimicrobial resistance have to be considered when studying traits in the environment, and one must consider the multitude of factors, including possible synergistic effects. Evidence here suggests that metal conditions and the presence of potentially toxic metals make a contribution to the spread of antimicrobial resistance. There are two possible cases for increased resistance development: (1) The amount of genes can increase, along with the amount of total bacteria, as evident following exposure to biochemical relevant elements, (2) or the increased selection of bacteria with resistance traits. The measurement type, whether absolute gene counts or relative abundances, can possibly explain elevated resistance.

Acknowledgments Funding for the project was provided by the University of Strathclyde Research Development Fund (\#2009-1551); many thanks to Dr. Seánín McCluskey for providing the standards and primers used in the study. Also thanks to the Centre for Ecosystem Management for funding the extraction of soil samples and Prof. Robert M. Kalin for hosting Andrea Hinwood, which prompted discussions that led to this project.

Open Access This article is distributed under the terms of the Creative Commons Attribution 4.0 International License (http:// creativecommons.org/licenses/by/4.0/), which permits unrestricted use, distribution, and reproduction in any medium, provided you give appropriate credit to the original author(s) and the source, provide a link to the Creative Commons license, and indicate if changes were made.

\section{References}

Abella J, Fahy A, Duran R, Cagnon C (2015) Integron diversity in bacterial communities of freshwater sediments at different contamination levels. FEMS Microbiol Ecol 91: fiv140

Alonso A, Sanchez P, Martinez JL (2001) Environmental selection of antibiotic resistance genes. Environ Microbiol 3:1-9

Ashbolt NJ, Amezquita A, Backhaus T, Borriello P, Brandt KK, Collignon P, Coors A, Finley R, Gaze WH, Heberer T, Lawrence JR, Larsson DGJ, McEwan SA, Ryan JJ, Schönfeld J, Silley P, Snape JR, Van den Eede C, Topp E (2013) Human health risk assessment (HHRA) for environmental development and transfer of antibiotic resistance. Environ Health Perspect 121:993-1001

Australian Institute of Health and Welfare (2004) Rural, regional and remote health: a guide to remoteness classifications http://www. aihw.gov.au/WorkArea/DownloadAsset.aspx?id=6442459567. Last accessed 04 August 2016.

Baker-Austin C, Wright MS, Stepanauskas R, McArthur JV (2006) Coselection of antibiotic and metal resistance. Trends Microbiol 14: 176-182

Bass L, Liebert CA, Lee MD, Summers AO, White DG, Thayer SG, Maurer JJ (1999) Incidence and characterization of integrons, genetic elements mediating multiple-drug resistance, in avian Escherichia coli. Antimicrob Agents Chemother 43:2925-2929

Beaber JW, Hochhut B, Waldor MK (2004) SOS response promotes horizontal dissemination of antibiotic resistance genes. Nature 427 : 72-74

Berendock TU, Manaia CM, Merlin C, Fatta-Kassinos D, Cytryn E, Walsh F, Bürgmann H, Sørum H, Norström M, Pons M-N, Kruenzinger N, Huovinen P, Stefani S, Schwartz T, Kisand V, Baquero F, Martinez JL (2015) Tackling antibiotic resistance: the environmental framework. Nat Rev Microbiol 13:310-317

Berg J, Thorsen MK, Holm PE, Jensen J, Nybroe O, Brandt KK (2010) $\mathrm{Cu}$ exposure under field conditions coselects for antibiotic resistance as determined by a novel cultivation-independent bacterial community tolerance assay. Environ Sci Technol 44:8724-8728

Berg J, Tom-Petersen A, Nybroe O (2005) Copper amendment of agricultural soil selects for bacterial antibiotic resistance in the field. Lett Appl Microbiol 40:146-151

Bernier SP, Surette MG (2013) Concentration-dependent activity of antibiotics in natural environments. Front Microbiol 4 
Callan AC, Hinwood AL, Ramalingam M, Boyce M, Heyworth J, McCafferty P, Odland JO (2013) Maternal exposure to metalsconcentrations and predictors of exposure. Environ Res 126:111-117

Canton R (2009) Antibiotic resistance genes from the environment: a perspective through newly identified antibiotic resistance mechanisms in the clinical setting. Clin Microbiol Infect 15:20-25

Davies J, Davies D (2010) Origins and evolution of antibiotic resistance. Microbiol Mol Biol Rev 74:417-433

Day PR (1965) Particle fractionation and particle-size analysis. In: Black CA (ed) Methods of soil analysis, part 1. American Society of Agronomy, Madison, WI, pp. 545-567

Dhakephalkar PK, Chopade BA (1994) High-levels of multiple metal resistance and its correlation to antibiotic-resistance in environmental isolates of Acinetobacter. Biometals 7:67-74

Dorn-In S, Bassitta R, Schwaiger K, Bauer J, Hölzel CS (2015) Specific amplification of bacterial DNA by optimized so-called universal bacterial primers in samples rich of plant DNA. J Microbiol Methods 113:50-56

Fraser WR (1971) Some features of antibiotic resistance in Staphylococci: mercury resistance and multiple antibiotic resistance. Proc Roy Soc Med 64:540-544

Ghosh A, Singh A, Ramteke PW, Singh VP (2000) Characterization of large plasmids encoding resistance to toxic heavy metals in Salmonella abortus equi. Biochem Biophys Res Commun 272:6-11

Graham DW, Olivares-Rieumont S, Knapp CW, Lima L, Werner D, Bowen E (2011) Antibiotic resistance gene abundances associated with waste discharges to the Almendares River near Havana, Cuba. Environ Sci Technol 45:418-424

Guo XC, Liu S, Wang Z, Zhang XX, Li M, Wu B (2014) Metagenomic profiles and antibiotic resistance genes in gut microbiota of mice exposed to arsenic and iron. Chemosphere 112:1-8

Hasman H, Aarestrup FM (2005) Relationship between copper, glycopeptide, and macrolide resistance among Enterococcus faecium strains isolated from pigs in Denmark between 1997 and 2003. Antimicrob Agents Chemother 49:454-456

Hinwood AL, Callan AC, Ramalingam M, Boyce M, Heyworth J, McCafferty P, Odland JO (2013) Cadmium, lead and mercury exposure in non-smoking pregnant women. Environ Res 126:118-124

Hölzel CS, Muller C, Harms KS, Mikolajewski S, Schafer S, Schwaiger K, Bauer J (2012) Heavy metals in liquid pig manure in light of bacterial antimicrobial resistance. Environ Res 113:21-27

Hu HW, Wang JT, Li J, Li JJ, Ma YB, Chen D, He JZ (2016) Field-based evidence for copper contamination induced changes of antibiotic resistance in agicultural soils. Environ Microbiol. doi:10.1111 /1462-2920.13370

Ji XL, Shen QH, Liu F, Ma J, Xu G, Wang YL, Wu MH (2012) Antibiotic resistance gene abundances associated with antibiotics and heavy metals in animal manures and agricultural soils adjacent to feedlots in Shanghai, China. J Hazard Mater 235:178-185

Knapp CW, Dolfing J, Ehlert PAI, Graham DW (2010) Evidence of increasing antibiotic resistance gene abundances in archived soils since 1940. Environ Sci Technol 44:580-587

Knapp CW, Lima L, Olivares-Rieumont S, Bowen E, Werner D, Graham DW (2012) Seasonal variations in antibiotic resistance gene transport in the Almendares River, Havana. Cuba Front Microbiol 3

Knapp CW, McCluskey SM, Singh BK, Campbell CD, Hudson G, Graham DW (2011) Antibiotic resistance gene abundances correlate with metal and geochemical conditions in archived scottish soils PLoS One 6

Li J, Ma YB, Hu HW, Wang JT, Liu YR, He JZ (2015) Field-based evidence for consistent responses of bacterial communities to copper contamination in two contrasting agricultural soils. Front Microbiol 6:31

Marques AM, Congregado F, Simonpujol DM (1979) Antibiotic and heavy-metal resistance of Pseudomonas aeruginosa isolated from soils. J Appl Bacteriol 47:347-350
Martinez JL (2008) Antibiotics and antibiotic resistance genes in natural environments. Science 321:365-367

Martinez JL (2009) Environmental pollution by antibiotics and by antibiotic resistance determinants. Environ Pollut 157:2893-2902

McLaughlin MJ, Lofts S, Warne M, Amorim MJB, Fairbrother A, Lanno R, Hendershot W, Schelkat CE, Ma Y, Paton GJ (2010) Derivation of ecological based soil standards for trace elements. In: Merrington $\mathrm{G}$, Schoeters I (eds) Soil quality standards. SETAC Press, Pensacola, FL

NEPC (1999) National Environment Protection (Assessment of Contaminated Land) Measure 1999. Schedule B (7a) Guideline on Health Investigation Levels. National Environment Protection Council.

Ng LK, Martin I, Alfa M, Mulvey M (2001) Multiplex PCR for the detection of tetracycline resistant genes. Mol Cell Probes 15: 209-215

Nisanian M, Holladay SD, Karpuzoglu E, Kerr RP, Williams SM, Stabler L, Vaun McArthur J, Tuckfield RC, Gogal RM Jr (2014) Exposure of juvenile Leghorn chickens to lead acetate enhances antibiotic resistance in enteric bacterial flora. Poult Sci 93:891897

Palm GJ, Lederer T, Orth P, Saenger W, Takahashi M, Hillen W, Hinrichs W (2008) Specific binding of divalent metal ions to tetracycline and to the tet repressor/tetracycline complex. J Biol Inorg Chem 13: $1097-1110$

Peak N, Knapp CW, Yang RK, Hanfelt MM, Smith MS, Aga DS, Graham DW (2007) Abundance of six tetracycline resistance genes in wastewater lagoons at cattle feedlots with different antibiotic use strategies. Environ Microbiol 9:143-151

Pei RT, Kim SC, Carlson KH, Pruden A (2006) Effect of river landscape on the sediment concentrations of antibiotics and corresponding antibiotic resistance genes (ARG). Water Res 40:2427-2435

Peltier E, Vincent J, Finn C, Graham DW (2010) Zinc-induced antibiotic resistance in activated sludge bioreactors. Water Res 44:3829-3836

Perry J, Wright G (2013) The antibiotic resistance "mobilome": searching for the link between environment and clinic. Front Microbiol 4:138

Pruden A, Pei RT, Storteboom H, Carlson KH (2006) Antibiotic resistance genes as emerging contaminants: studies in northern Colorado. Environ Sci Technol 40:7445-7450

Richmond MH, Parker M, Jevons MP, John M (1964) High penicillinase production correlated with mulitiple antibiotic resistance in Staphylococcus aureus. Lancet: 293-296

Rhoades JD (1982) Soluble salts, methods of soil analysis, part 2. Chemical and Microbiological Properties. American Society of Agronomy Monograph No. 9, 2nd ed.

Roberts M (2012) Acquired tetracycline resistance genes. In: Dougherty T, Pucci M (Eds.), Antibiotic Discovery and Development, pp 543-568

Schollenberger CJ (1945) Determination of soil organic matter. Soil Sci 59:53-56

Schulte EE, Hopkins BG (1996) Estimation of soil organic matter by weight loss-on-ignition. pp 21-31

Seiler C, Berendonk TU (2012) Heavy metal driven co-selection of antibiotic resistance in soil and water bodies impacted by agriculture and aquaculture Front Microbiol 3

Shlaes DM (2010) Antibiotics. The Perfect Storm, Springer, Dordrecht

Sheldrick BH, Wang C (1993) Soil sampling and methods of analysis. Canadian Society of Soil Science. Lewis Publishers, Ann Arbor

Smith MS, Yang RK, Knapp CW, Niu YF, Peak N, Hanfelt MM, Galland JC, Graham DW (2004) Quantification of tetracycline resistance genes in feedlot lagoons by real-time PCR. Appl Environ Microbiol 70:7372-7377

Stepanauskas R, Glenn TC, Jagoe CH, Tuckfield RC, Lindell AH, King CJ, McArthur JV (2006) Coselection for microbial resistance to metals and antibiotics in freshwater microcosms. Environ Microbiol 8:1510-1514

Stepanauskas R, Glenn TC, Jagoe CH, Tuckfield RC, Lindell AH, McArthur JV (2005) Elevated microbial tolerance to metals and 
antibiotics in metal-contaminated industrial environments. Environ Sci Technol 39:3671-3678

Su JQ, Wei B, Ou-Yang WY, Huang FY, Zhao Y, Xu HJ, Zhu Y-G (2015) Antibiotic resistome and its association with bacterial communities during sewage sludge composting. Environ Sci Technol 49: $7356-7363$

Tenover FC (2006) Mechanisms of antimicrobial resistance in bacteria. Amer J Infect Cont 34:S3-S10

Timoney JF, Port J, Giles J, Spanier J (1978) Heavy-metal and antibiotic resistance in bacterial flora of sediments of New York bight. Appl Environ Microbiol 36:465-472

USEPA (2002) Method 3050B. Acid Digestion of Sediment, Sludges and Soils. US Environmental Protection Agency, Washington DC
Van Reeuwijk LP (2002) Procedures for soil analysis (6th edition). International Soil Reference and Information Centre, Food and Agriculture Organisation of the United Nations

WHO (2014) Global Report on Surveillance. World Health Organisation. Wright MS, Peltier GL, Stepanauskas R, McArthur JV (2006) Bacterial tolerances to metals and antibiotics in metal-contaminated and reference streams. FEMS Microbiol Ecol 58:293-302

Yamaguchi A, Udagawa T, Sawai T (1990) Transport of divalent cations with tetracycline as mediated by the transposon Tn10-encoded tetracycline resistance protein. J Biol Chem 265:4809-4813

Zhu Y-G, Johnson TA, Su JQ, Qiao M, Guo GX, Stedfeld RD, Hashsham SA, Tiedje JM (2013) Diverse and abundant antibiotic resistance genes in Chinese swine farms. Proc Natl Acad Sci U S A 110: 3435-3344 